pices : it was tentatively created for two years, and three technically trained forest officers were appointed. The fourth annual report of the then young Department (it had passed the two-year ordeal successfully) was issued in 1926 and was reviewed in Nature (119, $256 ; 1927)$. 'The following extract from this review merits reproducing: ". . . it is easy to see that the young department has already made good. So far, the work has been mainly devoted to assisting the several lumbering companies at work in the forests on government leases. In, some respects the operations are proceeding on lines similar to the working of the Burmese forests by the British forest officers of earlier days. Obviously, however, the work of exploring the government forests, collecting topographical and other details, has been commenced (the superior staff now amounting to six), and it is hoped to be able to carry out the exploration of the practically unknown territory of the Western Highlands. ... At the time of writing, a reliable base-line has been established between Vaca and the Rio Grande and a good general idea of the forests of this region obtained". That was twenty-seven years ago. The extracts from the present report already given indicate the history of the Forest Department since then and the ignorance on the part of the authorities of the value of the forest estate to the people and the Colony itself.

E. P. Stebbing

\section{CAMBRIDGE UNIVERSITY EDUCATIONAL FILM COUNCIL}

$\mathrm{T}$ HE seventh annual report of the Cambridge University Educational Film Council states that Prof. J. F. Baker has succeeded Sir Lawrence Bragg as president and that two new vice-presidents, Mr. S. C. Roberts, master of Pembroke College, and Prof. J. A. Steers, head of the Department of Geography, have been appointed. With the use of a Merlin Gerin camera in the Department of Engineering, a number of 16-mm. ciné pictures at 4,000 frames per second. of tensile specimens being broken have been obtained. Some medium-speed pictures, at 100 frames per second, of the operation of a new testing machine have been taken; cinematography is also being used in connexion with the flow of gases in internal combustion engines. Members of the Departments of Anatomy and of Physiology have collaborated in the making of a film, "The Behaviour of Dissociated Sponge Cells". The use of films in teaching has been maintained especially in the University Faculties and Departments of Anatomy, Archæology and Anthropology, Economics and Politics, Engineering, Geography, Slavonic Studies and Zoology. In the Department of Education lectures on the use of visual aids continue as a regular part of the course. In a continuation of the film sessions for students of history, the films "Peter the Great", "Kameradschaft", "Day of Wrath", "Ivan the Terrible", "Journey into History", "Images Crothiques" and "Ange de la Paix" have been shown. The purchase of some $16-\mathrm{mm}$. editing apparatus has improved film-making facilities in the University. There remains, however, the need for a central cutting room, and an arrangement by which films may be processed within the University.

A proposal discussed between the Film Council and a member of the B.B.C. Television Service may greatly assist the making of films in the University.
Film-making facilities would be provided, and also a copy of any film used, in return for the provision of suitable science subjects for television programmes. The Film Council again urges that all the films made in Cambridge by the late Sir Joseph Barcroft should be traced and catalogued, and, where necessary, edited, copied and preserved. The Council has also recommended further Cambridge films for inclusion in the Scientific Film Library. Projection arrangements are much as they were a year ago, and there is still a lack of continuous $35-\mathrm{mm}$. projection facilities in the University.

\section{EVIDENCE OF FIRE IN SOUTH AFRICAN CAVE DEPOSITS}

\section{Dr. KENNETH P. OAKLEY \\ British Museum (Natural History)}

IN 1947 great interest was aroused by Prof. Raymond Dart's announcement that evidence had been found at the Limeworks in the Makapansgat Valley, Central Transvaal, that Australopithecus was a user of fire. He based this conclusion on Dr. V. L. Bosazza's identification of fragments of a brown glass-like substance in the basal grey beds there which had yielded remains of this hominid. The vitreous material was regarded as having resulted from the action of fire in the presence of lime, phosphates and $\mathbf{a s h}^{1}$.

Some anthropologists have doubted these conclusions. There is no evidence that Australopithecus was a tool-maker, and on general grounds it appenrs most unlikely that the use of fire preceded the manufacture of tools. Moreover, three other possible explanations of the vitreous material in the Makapan deposit might be advanced: although siliceous and vitreous in appearance, it may have been produced by some chemical action not requiring a high temperature ; even if the material is true glass, it may have been due to fires ignited by men living contemporaneously with Australopithecus; or it may have been produced by fires ignited at the mouth of the cave by some natural conflagration.

The second possibility certainly has to be taken more seriously now that there is evidence indicating that tool-making hominids (that is, 'men' in common parlance) were living contemporaneously with Australopithecines in South Africa ${ }^{2}$. The idea that the vitreous material possibly originated through a natural conflagration might seem more far-fetched; but quite recently evidence has come from the Cave of Hearths, farther up the Makapansgat Valley, which shows that this, too, is at least a plausible hypothesis.

Through the courtesy of Prof. C. van Riet Lowe, I had an opportunity in March 1953 of visiting the Makapan sites in company with him and with Prof. and Mrs. Dart. At the Cave of Hearths, I was much impressed by the thickness (more than $4 \mathrm{ft}$.) of what appeared to be eindery ash forming the so-called basal hearth in the Upper Acheulean zone of the cultural sequence. This 'hearth' is generally regarded as the oldest proved evidence of the use of fire by Stone Age man in Africa. I was, however, puzzled by two features of the ash : (1) it appeared to contain no fragments of charcoal or burnt bone; (2) it rested directly on a clean surface of stalagmitic drip. 